\title{
Influence of microstructure on the microbial corrosion behaviour of stainless steels $(\cdot)$
}

\author{
Diego Alejandro Moreno*, José Ramón Ibars* and Carlos Ranninger*
}

\begin{abstract}
Several stainless steels (Types UNS S30300, S30400, S30403, S31600, S31603 and S42000) with different microstructural characteristics have been used to study the influence of heat treatments on microbiologically influenced corrosion (MIC). Biocorrosion and accelerated electrochemical testing was performed in various microbiological media. Two species of sulphate-reducing bacteria (SRB) have been used in order to ascertain the influence of microstructure. The morphology of corrosion pits produced in both chloride and chloride plus sulphide -SRB metabolites- was inspected by optical and scanning electron microscopy (SEM) complemented with energy-dispersive X-ray (EDX) analysis. Results have shown different behaviours regarding corrosion resistance in each case studied. Sensitized austenitic stainless steels were more affected by the presence of aggressive anions and pitting potential (Ep) values were more cathodic than those of as-received state. A corrosion enhancement is produced by the synergistic action of biogenic sulphides and chloride anions. Pitting corrosion in martensitic stainless steel Type UNS S42000 was found in a biocorrosion test. The pitting morphology is correlated to the chemical composition, the microstructure and the electrolyte.
\end{abstract}

Keywords Microbiologically influenced corrosion (MIC). Stainless steel. Sulphatereducing bacteria (SRB). Biocorrosion test. Electrochemical test.

\section{Influencia de la microestructura en el comportamiento frente a la corrosión microbiana de los aceros inoxidables}

Resumen Se han utilizado aceros inoxidables de los tipos UNS S30300, S30400, S30403, S31600, S31603 y S42000, en diferentes estados microestructurales, para estudiar la influencia de los tratamientos térmicos sobre la corrosion microbiana. Para ello, se han realizado ensayos electroquímicos y ensayos de biocorrosión, en diferentes medios microbiológicos, utilizándose dos especies de bacterias reductoras de sulfatos (SRB). La morfología de las picaduras, producidas en presencia de cloruros y en presencia de cloruros más sulfuros -metabolitos de SRB-, se ha analizado por microscopía óptica y por microscopía electrónica de barrido (SEM) complementada con análisis por energía dispersiva de rayos X (EDX). En cada estado microestructural estudiado se han observado diferentes comportamientos en relación con su resistencia a la corrosión microbiana. Los aceros inoxidables austeníticos sensibilizados fueron más afectados por la presencia de aniones agresivos y los valores del potencial de picadura (Ep) fueron más catódicos que en estado de recepción. Así mismo, se produce un incremento de la corrosión por la acción sinérgica entre los aniones cloruros y los sulfuros biogénicos. Se ha encontrado, en uno de los ensayos de biocorrosión, picaduras en el acero inoxidable martensítico del tipo UNS S42000. Se correlaciona la morfología observada en las picaduras con la composición química, la microestructura y el electrólito.

Palabras clave Corrosión microbiana (MIC). Acero inoxidable. Bacteria reductora de sulfatos (SRB). Ensayo de biocorrosión. Ensayo electroquímico.

(•) Trabajo recibido el día 28 de abril de 2000 y aceptado en su forma final el 16 de agosto de 2000.

(*) Dpto. de Ingeniería y Ciencia de los Materiales. E.T.S.I. Industriales. Universidad Politécnica de Madrid. José Gutiérrez Abascal, 2. E-28006 Madrid (España). 


\section{INTRODUCTION}

The participation of microorganisms in the corrosion processes of steels was established and researched in depth in the last decades ${ }^{[1-3]}$. In 1983 Tiller asked himself whether stainless steels were susceptible of biocorrosion processes and provided an answer with two practical cases ${ }^{[4]}$. It was during the Eighties when a large number of corrosion problems caused by microorganisms were reported in stainless steels ${ }^{[5]}$.

Thus, there have had descriptions of service failures in stainless steels of the Types UNS $\mathrm{S} 30400^{[6-13]}, \mathrm{S} 30403^{[11,13}$ and 14$], \mathrm{S} 31600^{[9,11}$ and 13$]$, $\mathrm{S} 31603^{[9}$ and $\left.13-15\right], \mathrm{S} 30300^{[6]}$ and also of a $13 \% \mathrm{Cr}$ and $1 \% \mathrm{Ni}$ martensitic stainless steel ${ }^{[12]}$. The corrosion of these stainless steels raises major problems in key industrial sectors where they are regularly chosen on account of their corrosion resistance.

The examination of biological deposit materials associated with the areas in which this type of corrosion has been detected reveals the existence of microorganisms. The oxidizing filamentous bacteria of iron (genus Gallionella amongst others) are the ones most frequently associated, in the first place, with the microbiologically influenced corrosion (MIC) of stainless steels. Their action is associated with the sulphate-reducing bacteria (SRB), which are the ones directly responsible for pitting and, therefore, for the corrosion of the material.

In practically all cases this type of corrosion manifests itself in the form of pitting and occasionally stress induced cracking under biofilms and biodeposits. The pits and cracks are frequently localized under the biological deposit material in areas adjacent to welds -heat affected zones ${ }^{[9]}$. The external hole of the pits is usually small with a large subsuperficial cavity. The biodeposits are rich in iron with significant amounts of manganese and silicon. Sulphur and phosphorus may sometimes be found. Chlorine is often present in pits.

Pits sometimes appear in the weld deposited material, generally close to the fusion line. Neither of the two phases (austenite and ferrite) that appear in these welds is excluded from attack ${ }^{[13]}$. In some situations austenite is subject to preferable attack. In other cases delta ferrite is attacked in preference to austenite ${ }^{[16]}$.

In the case of ferritic or martensitic stainless steels, there is even less information available. There does seem to be some relation with the microstructural state; carbide stability may play a significant role in this. In such a case, the asreceived annealed state behaves better in terms of corrosion than the quench and tempered states, especially if carried out at low temperatures. ${ }^{[17]}$

In any case, it seems that more research must be done on this topic so that the microstructural state of the materials that undergo MIC being determined in a more precise and quantitative way.

The main aim of this study is to analyze the susceptibility of several stainless steels in different microstructural states to microbial corrosion by both biocorrosion and electrochemical corrosion tests.

\section{EXPERIMENTAL METHODS}

\subsection{Materials and heat treatments}

The stainless steels used, in the form of split tubes and plates, were austenitic and martensitic of the Types UNS S30300, S30400, S30403, S31600, S31603 and S42000, with the chemical compositions showed in table I. All are widely used in industry ${ }^{[18]}$ and have exhibited microbial corrosion problems ${ }^{[5]}$.

Table I. Chemical composition of stainless steels tested (\% weight)

Tabla I. Composición química de los aceros inoxidables ensayados (\% en peso)

\begin{tabular}{cccccccccc}
\hline Specimen & C & Si & Mn & S & P & Cr & Mo & Ni & PRE $^{(*)}$ \\
\hline UNS S30300 & 0.038 & 0.24 & 1.53 & 0.220 & 0.033 & 18.1 & 0.20 & 8.0 & 18.70 \\
UNS S30400 & 0.062 & 0.48 & 1.17 & 0.005 & 0.027 & 18.1 & 0.60 & 7.5 & 19.90 \\
UNS S30403 & 0.006 & 0.41 & 1.30 & 0.010 & 0.027 & 19.1 & 0.21 & 10.0 & 19.73 \\
UNS S31600 & 0.040 & 0.61 & 1.16 & 0.003 & 0.019 & 18.0 & 3.00 & 10.0 & 27.00 \\
UNS S31603 & 0.012 & 0.51 & 1.60 & 0.001 & 0.027 & 18.1 & 2.75 & 12.4 & 26.35 \\
UNS S42000 & 0.270 & 0.88 & 0.67 & 0.005 & 0.021 & 14.3 & 0.05 & 0.0 & 14.45 \\
\hline
\end{tabular}

*PRE (Pitting resistance equivalent) $=\% \mathrm{Cr}+3 \% \mathrm{Mo}$ 
Two different states of heat treatment for each material have been tested: as-received and an individualized heat treatment depending on the characteristics of each material. Table II shows the heat treatment states in which the tests were conducted for each material.

Heat treatments were carried out with the criterion of substantially modifying the microstructural characteristics displayed by each material in the as-received state and with the idea of the state obtained having, at least in theory, a worse behaviour with regard to corrosion ${ }^{[19]}$.

The austenitic stainless steels were studied not only in the microstructural solution-annealed states, in which maximum uniformity of structure and optimum corrosion behaviour are obtained, but also in the microstructural sensitized states. Thus, in each of the austenitic stainless steels, sensitizing heat treatments at $675^{\circ} \mathrm{C}$ for varying times were carried out, selecting those that produced a ditch type structure as per ASTM A-262, Practice $A^{[20]}$.

In the case of martensitic stainless steel Type UNS S42000, the annealing heat treatment has been tested, which is the commonest as-received state, and the quenched and tempered state, which is its usual state in applications.

The microstructural study was carried out by means of optical microscopy. In the austenite stainless steels we used electrolytic etching with oxalic acid, according to the technique described in ASTM-262, Practice $A^{[20]}$. The microstructure of martensitic stainless steel has been studied by making the etching with Vilella's reagent ${ }^{[21]}$.

\subsection{Biocorrosion tests}

Two types of semicontinuous cultures (I and II) were prepared. Their characteristics are showed in table III. A 1.2 L glass reactor was used, which was

Table II. Heat treatments of stainless steels

Tabla II. Tratamiento térmico de los aceros inoxidables

\begin{tabular}{clc}
\hline Specimen & As-received state & Heat treatment \\
\hline UNS S30300 & Solution annealed & $675^{\circ} \mathrm{C} / 4 \mathrm{~h}$ \\
UNS S30400 & Solution annealed & $675^{\circ} \mathrm{C} / 1 \mathrm{~h}$ \\
UNS S30403 & Solution annealed & $675^{\circ} \mathrm{C} / 48 \mathrm{~h}$ \\
UNS S31600 & Solution annealed & $675^{\circ} \mathrm{C} / 48 \mathrm{~h}$ \\
UNS S31603 & Solution annealed & $675^{\circ} \mathrm{C} / 48 \mathrm{~h}$ \\
UNS S42000 & Annealed & Quenched $\left(975^{\circ} \mathrm{C} / 20\right.$ \\
& & min-air) and tempered \\
& & $\left(650^{\circ} \mathrm{C} / 1 \mathrm{~h}\right)$ \\
\hline
\end{tabular}

Table III. Characteristics of biocorrosion tests

Tabla III. Características de los ensayos de biocorrosión

\begin{tabular}{lcc}
\hline \multicolumn{1}{c}{ Characteristic } & $\begin{array}{c}\text { Biocorrosion } \\
\text { test I }\end{array}$ & $\begin{array}{c}\text { Biocorrosion } \\
\text { test II }\end{array}$ \\
\hline $\begin{array}{l}\text { Reactor working } \\
\text { volume }(\mathrm{L})\end{array}$ & 1.2 & 1.2 \\
Medium & Beckwith & $\begin{array}{c}\text { Postgate C } \\
3 \% \mathrm{NaCl}(\mathrm{wt} / \mathrm{vol})\end{array}$ \\
Inoculum & Desulfotomaculum sp. & $\begin{array}{c}\text { D. desulfuricans } \\
\text { (DMS 1926) }\end{array}$ \\
$\mathrm{D}\left(\mathrm{h}^{-1}\right)$ & 0.026 & 0.018 \\
$\mathrm{pH}$ & $7 \pm 0.2$ & $7 \pm 0.2$ \\
Temperature $\left({ }^{\circ} \mathrm{C}\right)$ & 30 & 30 \\
Anaerobiosis & $\mathrm{N}_{2}(99.9992 \%)$ & $\mathrm{N}_{2}(99.9992 \%)$ \\
$\mathrm{E}_{\mathrm{S2}-}(\mathrm{mV})$ & - & -625 \\
Materials tested & Refer to table I & Refer to table I \\
Testing time (days) & 60 & 60 \\
\hline
\end{tabular}

characterized by having a central tree that acts as a support for up to 10 test pieces or specimens ( 35 $\mathrm{mm} \times 15 \mathrm{~mm}$ ). Seven inlet and outlet ports, for nutrient medium, gas and measurement monitoring, completed the top part. It had a side connection for nutrient medium outflow.

The specimens were prepared by grinding with 180 and 800 grade $\mathrm{SiC}$ emery paper with wet rotation. Before being put into operation all the material was autoclaved at $121^{\circ} \mathrm{C}$ for $20 \mathrm{~min}$.

A strain of Desulfotomaculum sp. isolated from a sludge from a hydraulic power station in Cáceres, Spain $^{[22]}$ and a strain of Desulfovibrio desulfuricans DSM 1926 (Deutsche Sammlung von Mikroorganismen) were used. These SRB were conserved in refrigerator at $4{ }^{\circ} \mathrm{C}$ until the time of use, for which a milliliter of the sample was enriched in Postgate $\mathrm{B}$ medium ${ }^{[23]}$ at $30^{\circ} \mathrm{C}$ in specially designed anaerobiosis tubes ${ }^{[22]}$.

During all the culture period, sulphide concentration was monitored by means of a sulphide electrode ${ }^{[24]}$.

\subsection{Electrochemical corrosion tests}

\subsubsection{Electrolytes}

Two electrolytes were used: Electrolyte $\mathrm{A}$ and Electrolyte B.

Electrolyte A, recommended by ASTM G-61$1986^{[25]}, 3.56 \% \mathrm{NaCl}$ in weight $(3.7 \% \mathrm{wt} / \mathrm{vol}=$ $0.925 \mathrm{M}$ ), was prepared by dissolving $34 \mathrm{~g}$ of $\mathrm{NaCl}$ in $920 \mathrm{~mL}$ of distilled water, as $900 \mathrm{~mL}$ are 
consumed in every test with this electrolyte. It was deaereated with high purity nitrogen $(99.9992 \%)$ for at least $90 \mathrm{~min}$, stirring the solution continuously. The deaereation of the medium was discontinued when the test started, and the stirring when the cathodic cleaning was completed. The redox potential of the medium was $+100 \mathrm{mV}$ versus the saturated calomel electrode (SCE).

Electrolyte B was prepared from a culture of Desulfovibrio desulfuricans DSM 1926 in a modified (without $\mathrm{Fe}$ ) Postgate $\mathrm{C}$ medium with $3 \% \mathrm{NaCl}$ $(\mathrm{wt} / \mathrm{vol}=0.75 \mathrm{M})$ in semicontinuous culture. The medium should not be deaereated, although it was stirred during cathodic cleaning. The redox potential of the medium was $-450 \mathrm{mV}(\mathrm{SCE})$. The $\mathrm{pS}^{2-}$ was between 1 and 2 . When the $\mathrm{pS}^{2-}$ was more than 2 the electrolyte was regarded as unusable ${ }^{[26]}$.

\subsubsection{Preparation of the working electrodes}

Specimen was mounted with Struers number 5 resin; a hard thermosetting epoxy resin for retaining the edges, after being passivated with 25 $\%$ nitric acid (in weight) for $25 \mathrm{~min}$ at $50{ }^{\circ} \mathrm{C}$. Grinding of specimen was carried out with 800 grade emery paper by wet rotation $(100,240,600$ and 800). It was then washed for $30 \mathrm{~s}$ in an ultrasonic bath, using a non-passivating detergent, and after rinsing with distilled water was assembled in the working electrode holder.

\subsubsection{Polarization curves}

Electrochemical testing was performed using a potentiostat PAR 273. The calomel reference electrode used was a Radiometer K-401 with $\mathrm{KCl}$ salt bridge for sulphide free media, and a Radiometer K-701 with $\mathrm{KNO}_{3}$ salt bridge for sulphide media.

Prior to testing, cathodic cleaning of the working electrode was carried out (to electroreduce the oxides on the surface), which begins at $-1,300 \mathrm{mV}(\mathrm{SCE})$ and last $90 \mathrm{~s}$. The working electrode was immersed in the cell once the application of the potential has been initiated by the potentiostat. When the cathodic cleaning was finished the potentiostat read the open circuit potential of the specimen, beginning the anodic scan at a rate of $10 \mathrm{mV} / \mathrm{min}$; this initial potential was around $-900 \mathrm{mV}(\mathrm{SCE})$. The test was halted when the current density reached $250 \mu \mathrm{A} / \mathrm{cm}^{2}$.

The pitting potential Ep of each material was obtained from anodic polarization curves. The Ep was expressed as a range of values, corresponding the minimum to a current density of $15 \mu \mathrm{A} / \mathrm{cm}^{2}$ and the maximum to $150 \mu \mathrm{A} / \mathrm{cm}^{2}$.

After the test, the specimens were analyzed microscopically, and the tests were considered valid when no pitting occurred at the edge of the specimen or, if it appeared, when accompanied by further pitting distributed evenly over the rest of the surface. All the tests were conducted in triplicate.

\subsection{Biofilms and corrosion analysis}

The biofilms were analyzed by scanning electron microscopy (SEM). Freshly withdrawn coupons

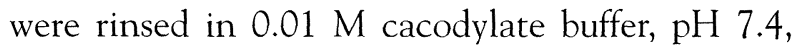
and fixed in $0.5 \%(\mathrm{vol} / \mathrm{vol})$ glutaraldehyde at $4{ }^{\circ} \mathrm{C}$ for at least $1 \mathrm{~h}$. They were then rinsed in cacodylate buffer and fixed for $3 \mathrm{~h}$ in $2.5 \%$ glutaraldehyde at $4{ }^{\circ} \mathrm{C}$. After washing three times in cacodylate buffer, the coupons were dehydrated through 30 to $100 \%$ acetone: water series $(30 \mathrm{~min}$ in each) and critically point dried. After, coupons were mounted onto aluminium stubs and sputter coated with gold and examined with a Jeol model 330-A scanning electron microscope at an accelerating voltage of $15-20 \mathrm{kV}$. The study of the biofilms was supplemented with energy-dispersive $\mathrm{X}$-ray (EDX) analysis.

The localized corrosion under the biofilms and the pits observed after electrochemical tests were studied by optical and SEM-EDX technique.

\section{RESULTS AND DISCUSSION}

\subsection{Microstructural analysis}

In the austenitic stainless steel Type UNS S30300 in the sensitized state, the carbide precipitation took place at the grain boundary and also at the slip bands (Fig. 1a). The grain boundary ditches are discontinuous (string of pits) and shallow, possibly due to the relatively low carbon content of the steel $(0.038 \%)$ and to the fact that the existence of a certain degree of cold deformation has distributed the carbide precipitation between the grain boundaries and the slip bands.

The austenitic stainless steel Type UNS S30400 in the sensitized state showed a marked carbide precipitation at the grain boundaries, giving rise to a structure with continuous grain boundary ditches (Fig. 1b). The degree of sensitization was apparently the same on the surface and in the 
interior of the material. There was no evidence that delta ferrite existed.

The austenitic stainless steel Type UNS S30403 was highly resistant to sensitization. With sensitizing heat treatment $\left(48 \mathrm{~h}\right.$ at $\left.675^{\circ} \mathrm{C}\right)$, slight sensitization took place with the appearance of isolated ditches at the grain boundaries (Fig. 1c).

Sensitizing heat treatment in austenitic stainless steel Type UNS S31600 induced the appearance of grain boundary ditches in the surface area (edge of the test specimen), denoting a marked chromium carbide precipitation (Fig. 1d), whereas in the interior there were no grain boundary ditches in significant amounts (Fig. 1e).

In the area close to the surface, the austenitic stainless steel Type UNS S31603 showed a certain tendency to sensitization (Fig. 1f).

The martensitic stainless steel Type UNS S42000 in the as-received state has a globulized carbide structure, while the matrix is ferrite. With quenching and tempering treatment, the structure is of tempered martensite and traces of globular carbides. Special heat treatment, with slow oven cooling, produced a microstructure similar to that of the as-received material, i.e. a globular carbide structure on a possibly ferritic matrix. The great amount of carbides present made it impossible to determine, with optical microscopy, whether the matrix was either ferrite or high temperature tempered martensite.

\subsection{Biofilm and corrosion analysis in biocorrosion tests}

After two months running of semicontinuous cultures, the reactor was disassembled to analyze the behaviour of the different stainless steels tested in different microstructural states.

In both cultures (I and II) the test specimens appeared coated with a thin black layer, which came away easily on washing them in sterile conditions with freshwater (culture I) or seawater (culture II), with the exception of the martensitic stainless steel Type UNS S42000, which displayed greater resistance to the removal of the biofilm. In carbon steels the biofilms are usually strongly adhered to the metal ${ }^{[27]}$.

The biofilms formed on stainless steel Type UNS S42000 had a blackish appearance due to the presence of iron sulphide. When analyzed by SEM, metabolic products were found mingled with the microorganisms used (Fig. 2). Qualitative EDX of the biofilms (Fig. 3) revealed an extremely high sulphur content. This peak was not found in the base metal (Fig. 4) confirming the formation of an iron sulphide rich film.

As regards the quality of the biofilm formed, differences between the two surface states cannot be established (ground with 180 and 800 grade $\mathrm{SiC}$ emery paper). There is some reference in the bibliography to the fact that surface state may have practical influence, because the small dimensions of the microorganisms allows their accommodation in the cavities on the material. A rough surface offers a larger area for the possible formation of biofilm. In very extreme cases, even different microenvironments could be detected in peaks and valleys ${ }^{[28]}$. However, once the layer is thick enough to cover the peaks, growth will be the same as takes place on a smooth surface.

The metallographic study of the coupons under the biofilms showed that stainless steel Type UNS S42000 in as-received state suffered pitting corrosion (Fig. 5). These pits had a non-equiaxed form. This appearance is reminiscent of pitting in case histories of microbial corrosion ${ }^{[5]}$. The pits produced in electrochemical tests were equiaxed. In the other stainless steels tested, the development of pitting after 60 days was not confirmed.

In the corrosion zone (Fig. 5) a halo or coloured area around it, similar to those produced in the electrochemical tests carried out in the presence of a medium with metabolites (Fig. 6), can be seen. EDX of the biofilms (Fig. 3) revealed the presence of sulphur, with a much higher peak than in the EDX carried out in an area close to pitting (Fig. 7) and even in the actual pit (Fig. 8). This may be explained by the thickness of the biofilm, in which corrosion products were trapped along with the bacteria (Fig. 2).

Weimer et al. ${ }^{[29]}$ did not find localized corrosion for stainless steels Types UNS S30400 and S31600 after 60 days continuous culture. However, they observed significant pitting in some parts of the stainless steel Type UNS S30400 reactor, which got continuously for 6 months or more into contact with the medium test.

Scott et al. ${ }^{[15]}$ found pits on an austenitic stainless steel, with a high molybdenum content, after batch cultures in the presence of both Desulfovibrio desulfuricans and Desulfotomaculum sp. Before test the material exhibited pits, which after 146 days became greater and also new pits occurred. The presence of high chloride concentrations (from the hypochlorites for biofilm 

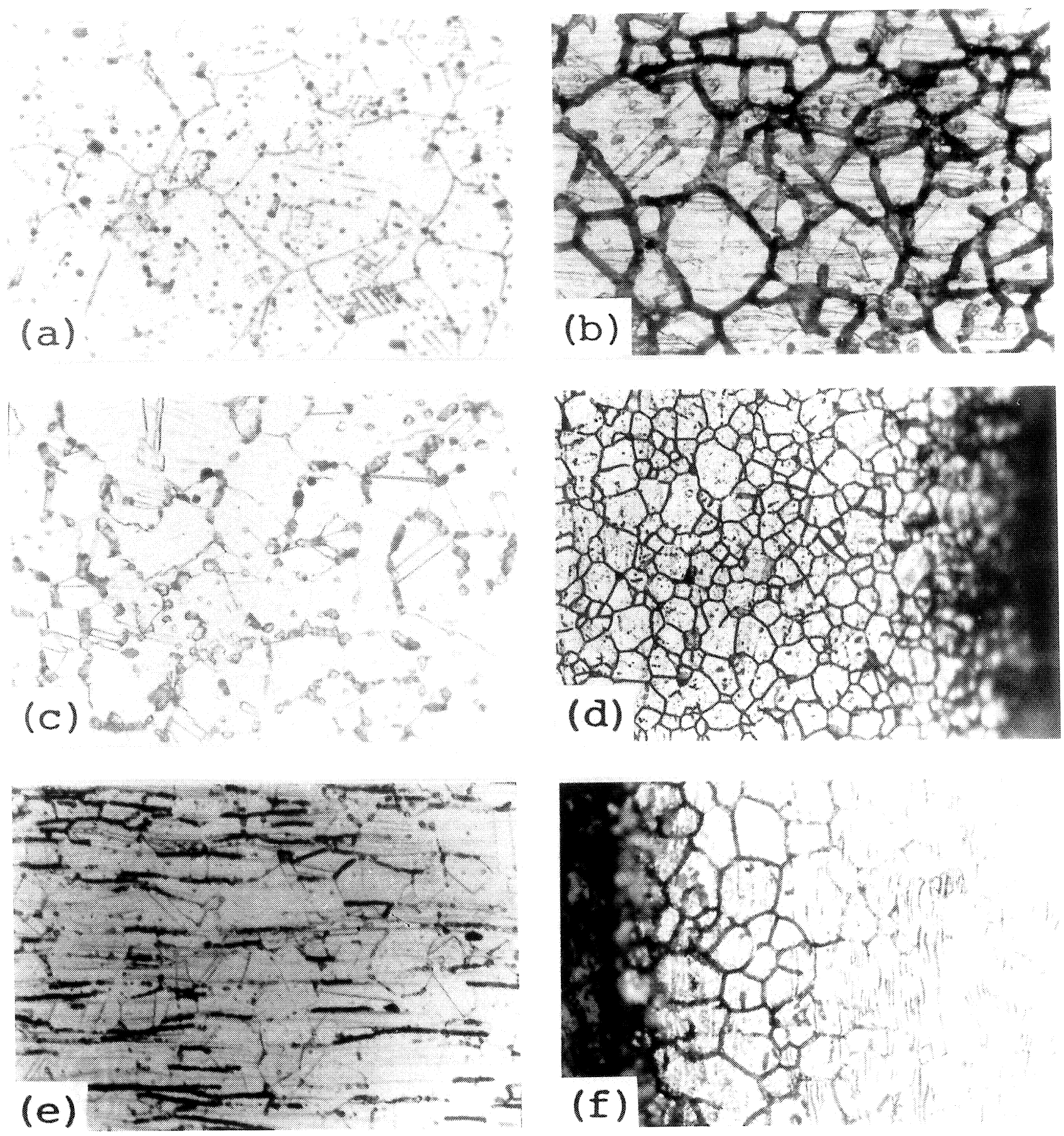

Figure 1. Stainless steels microstructures: a) Type UNS $S 30300$ sensitized $675^{\circ} \mathrm{C} / 4 \mathrm{~h}(400 \mathrm{x})$. b) Type UNS S30400 sensitized $675^{\circ} \mathrm{C} / 1 \mathrm{~h}(400 \mathrm{x})$. c) Type UNS S30403 sensitized $675^{\circ} \mathrm{C} / 48 \mathrm{~h}(400 \mathrm{x})$. d) Type UNS S31600 sensitized $675^{\circ} \mathrm{C} / 48 \mathrm{~h}$ specimen edge (200x). e) Type UNS S31600 sensitized $675^{\circ} \mathrm{C} / 48 \mathrm{~h}$, specimen centre (400x). f) Type UNS S31603 sensitized $675^{\circ} \mathrm{C} / 48 \mathrm{~h}$, specimen edge (200x)

Figura 1. Microestructuras de los aceros inoxidables: a) Tipo UNS 530300 sensibilizado $675^{\circ} \mathrm{C} / 4 \mathrm{~h}(x 400)$. b) Tipo UNS S30400 sensibilizado $675^{\circ} \mathrm{C} / 1 \mathrm{~h}(\times 400)$. c) Tipo UNS $S 30403$ sensibilizado $675^{\circ} \mathrm{C} / 48 \mathrm{~h}(x 400)$. d) Tipo UNS S31600 sensibilizado $675^{\circ} \mathrm{C} / 48 \mathrm{~h}$, borde de la probeta (x200). e) Tipo UNS $S 31600$ sensibilizado $675{ }^{\circ} \mathrm{C} / 48 \mathrm{~h}$, centro de la probeta (x400). f) Tipo UNS 531603 sensibilizado $675^{\circ} \mathrm{C} / 48 \mathrm{~h}$, borde de la probeta (x200).

control) was revealed as the casual agent of these corrosions.

The test specimens used in this study were weighed before and after testing and no weight loss was found. In another study ${ }^{[30]}$ stainless steel Type
UNS S42000 underwent a weight loss of 1.76 $\mathrm{mg} / \mathrm{dm}^{2}$ day $(\mathrm{mdd})$ after a 260 days culture. This is the only case found in the bibliography of weight loss for a stainless steel tested with laboratory cultures. 


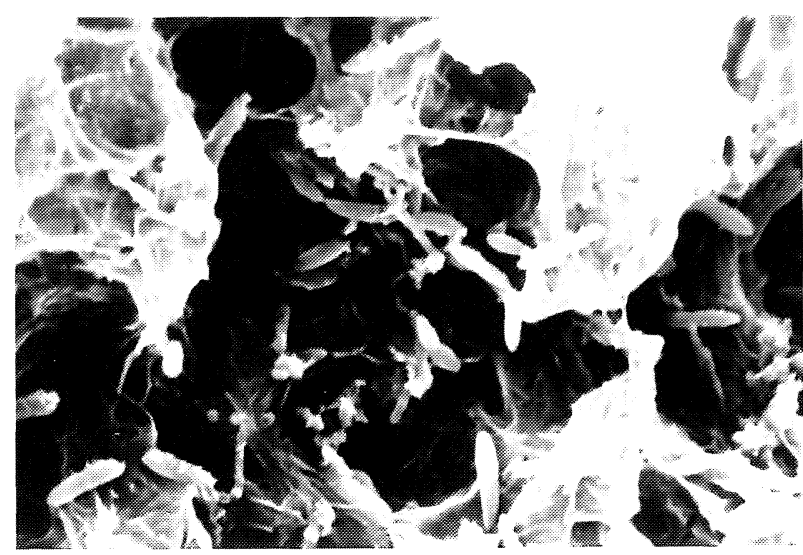

Figure 2. Biofilm of sulphate-reducing bacteria on stainless steel Type UNS S42000 (as-received state) $(5,000 x)$ (Printing reproduction at $50 \%$ ).

Figura 2. Biopelícula de bacterias reductoras de sulfatos sobre el acero inoxidable UNS 542000 en estado de recepción (x5.000) (Reproducida en imprenta al 50 \%).

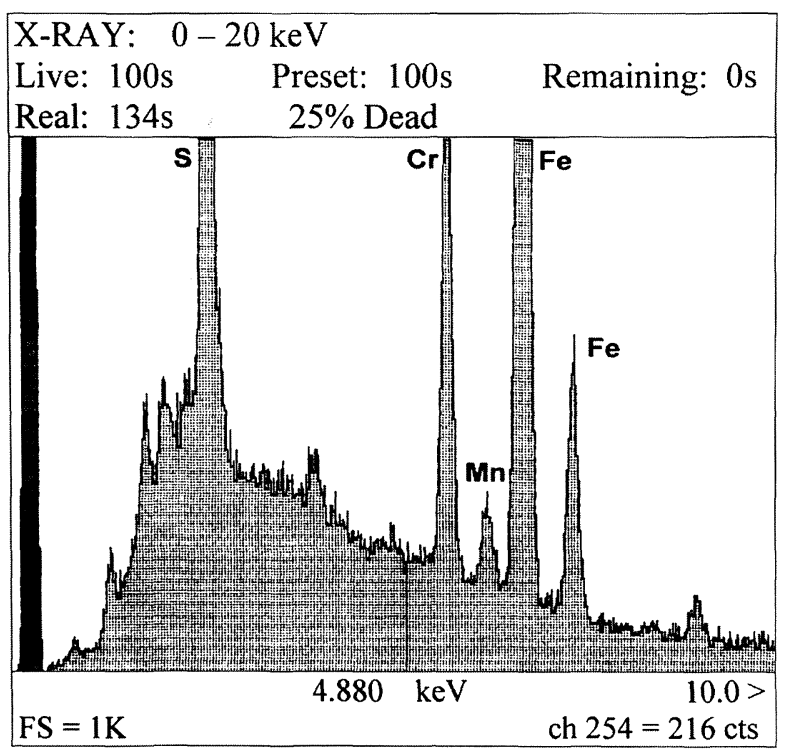

Figure 3. EDX analysis of biofilm on stainless steel Type UNS S42000.

Figura 3. EDX de la biopelícula sobre el acero inoxidable UNS $S 42000$.

\subsection{Sulphide layers in electrochemical tests}

In the curves corresponding to the anodic scan carried out on the test specimens of the stainless steels, in a medium of chlorides and sulphides (SRB metabolites), two peaks were observed: one at around $-200 \mathrm{mV}(\mathrm{SCE})$ and other at -40 $\mathrm{mV}(\mathrm{SCE})^{[26]}$. The size of these peaks is directly proportional to the sulphide concentration in the electrolyte; this aspect had been described previously ${ }^{[31]}$. In the absence of sulphides these

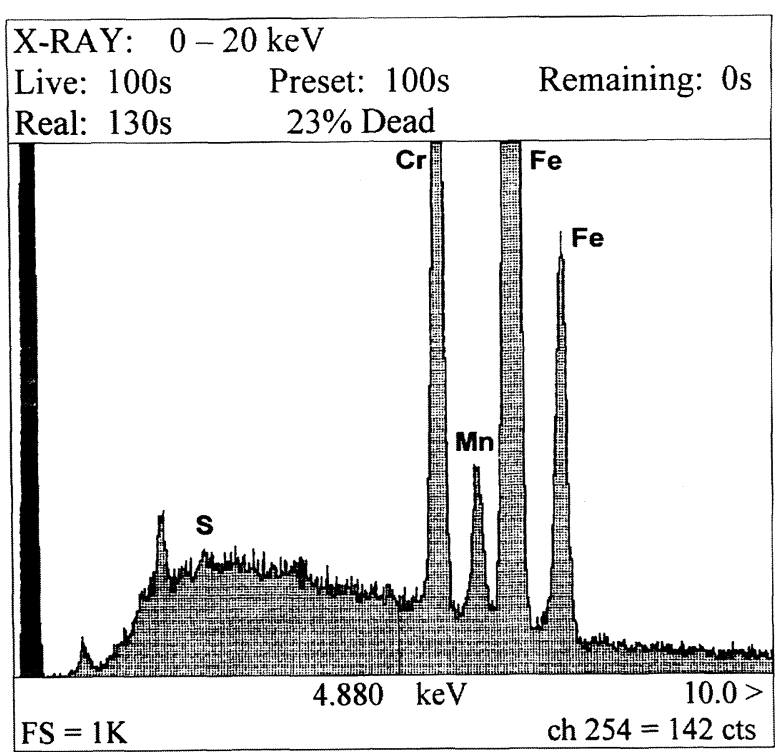

Figure 4. EDX analysis on stainless steel Type UNS 42000 after removing biofilm.

Figura 4. EDX sobre el acero inoxidable UNS S42000 después de eliminada la biopelícula.

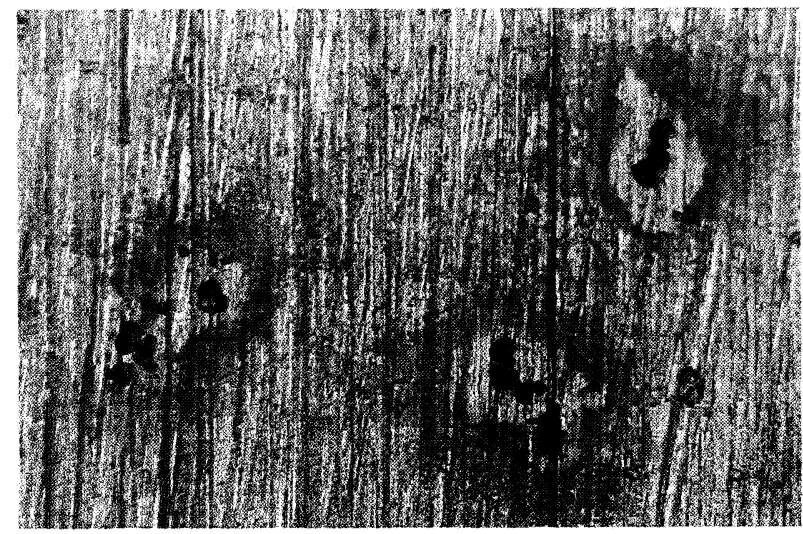

Figure 5. Pitting corrosion attack by sulphate-reducing bacteria on stainless steel Type UNS $\$ 42000$ annealed (50x) (Printing reproduction at $53 \%$ ).

Figura 5. Corrosión por picaduras por bacterias reductoras de sulfatos sobre el acero inoxidable UNS $\$ 42000$ recocido (x50) (Reproducida en imprenta al $53 \%$ ).

peaks disappear and the pitting potential (Ep) is identical to that of a chloride solution without sulphides. Therefore, the tests were considered valid only when the $\mathrm{pS}^{2-}$ had a value between 1 and 2, the area in which the peaks were highest. At these concentrations a grey coloured layer or thin film was produced which did not appear at lower concentrations. EDX close to the pits revealed the presence of sulphur (Fig. 7) not present in the base material. These results indicate that the film must be a sulphide film. However, for Cristofaro et al. ${ }^{[31]}$ 


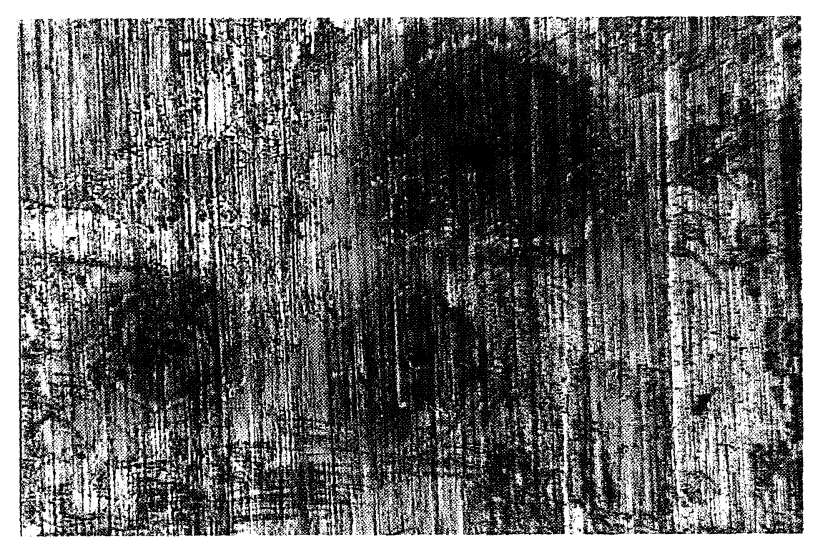

Figure 6. Pitting corrosion on stainless steel Type UNS S30400 sensitized after an electrochemical test using Electrolyte B (50x) (Printing reproduction at $53 \%$ ).

Figura 6. Corrosión por picaduras, sobre el acero inoxidable UNS 530400 sensibilizado, después de un ensayo electroquímico en el Electrólito $B(x 50)$ (Reproducida en imprenta al $53 \%$ ).

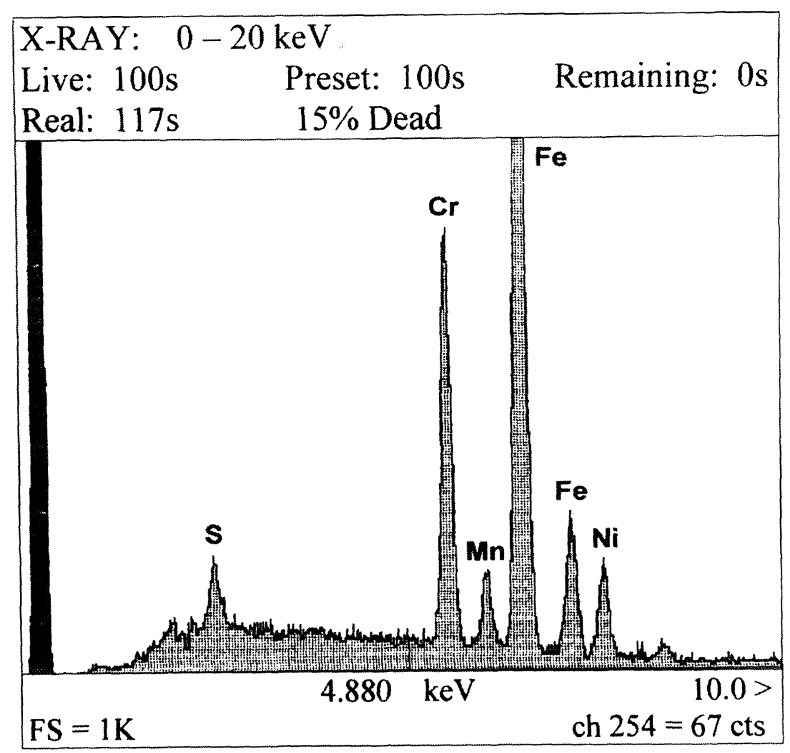

Figure 7. EDX analysis close to pitting on stainless steel Type UNS S31600 sensitized after an electrochemical test using Electrolyte B.

Figura 7. EDX en el área próxima a la picadura, en el acero inoxidable UNS S31600 sensibilizado, después de un ensayo electroquímico en el Electrólito $B$.

it may be formed by traces of sulphur or polysulphides.

In the mentioned concentrations a greater aggressiveness on the material was detected. In the presence of sulphur it seems that imperfect oxide layers are formed ${ }^{[31]}$. The alteration of the oxide layers produces the Ep drop when other aggressive anions, chlorides, are present.

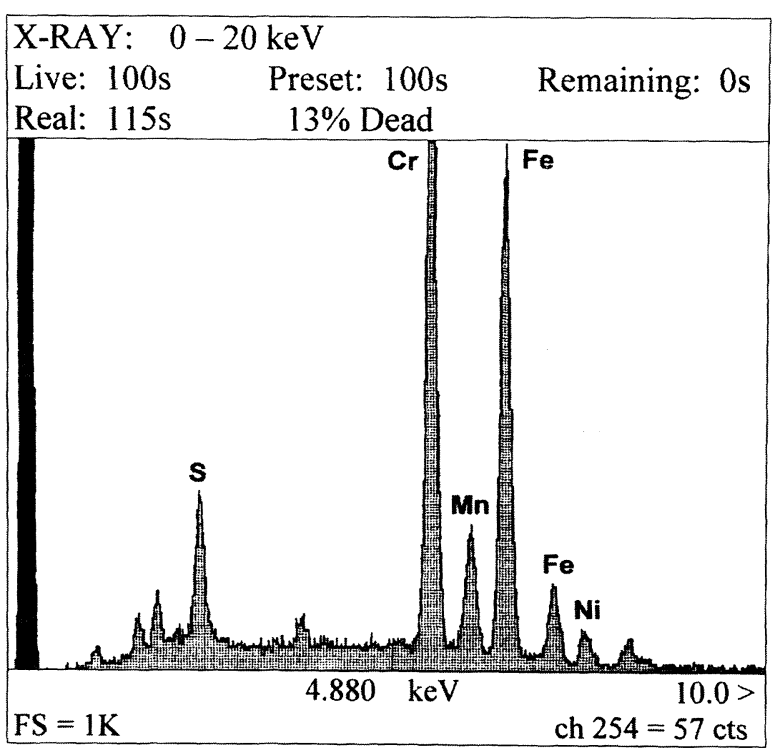

Figure 8. EDX analysis in pitting hole on stainless steel Type UNS S31600 sensitized after an electrochemical test using Electrolyte B.

Figura 8. EDX en el interior de la picadura, en el acero inoxidable UNS S31600 sensibilizado, después de un ensayo electroquímico en el Electrólito $B$.

The presence of the sulphide layer, which has a clear influence on the Ep, affects the morphology of the pits and their colouring.

In this study, variations in $\mathrm{S}^{2}$ - content of Electrolyte B were observed as the time increased. This electrolyte was obtained from semicontinuous cultures and contained aggressive chlorides and sulphides (SRB metabolites). The sulphides had a tendency to disappear from it due to their volatilization as $\mathrm{H}_{2} \mathrm{~S}$ and oxidation in aerobic conditions. The $\mathrm{pS}^{2-}$ was about than 3 after $24 \mathrm{~h}$. In these concentrations, during the anodic scanning, the sulphides are apparently insufficient to form a rich layer on the stainless steels, which behave, from the electrochemical point of view $(\mathrm{Ep})$, in the same way as when there are only chlorides in the medium.

\subsection{Polarization curves. Pitting potentials}

In table IV the pitting potential corresponding to each material and heat treatment state in Electrolytes A and B, respectively, are shown.

To analyze the results it must be noted that the higher pitting potential value is related with the greater resistance offered by the material to this type of corrosion; the extent of the corrosion area is directly related to the time the pits take to develop after nucleation. 
Influence of microstructure on the microbial corrosion behaviour of...

Table IV. Pitting potentials corresponding to the stainless steels tested at different microstructural states (in $\mathrm{mV}$ versus SCE) Tabla IV. Potenciales de picadura de los aceros inoxidables ensayados en diferentes estados microestructurales (en mV versus SCE)

\begin{tabular}{lcccc}
\hline Specimen & \multicolumn{2}{c}{ Electrolyte A } & \multicolumn{2}{c}{ Electrolyte B } \\
\cline { 2 - 5 } & As-received & Heat treated & As-received & Heat treated \\
UNS S30300 & 25 to 75 & -50 to 0 & 75 to 100 & 50 to 80 \\
UNS S30400 & 330 to 360 & -100 to 40 & 75 to 100 & -10 to 25 \\
UNS S30403 & 350 to 375 & 0 to 50 & 175 to 190 & 25 to 70 \\
UNS S31600 & 330 to 400 & 30 to 130 & 270 to 300 & 50 to 150 \\
UNS S31603 & 525 to 550 & -100 to -20 & 390 to 450 & -30 to 75 \\
UNS S42000 & -250 to -100 & -300 to -250 & -350 to -300 & -335 to -260 \\
\hline
\end{tabular}

\subsubsection{Pitting potentials in Electrolyte $A$}

The pitting potentials obtained for each material in its different states of heat treatment in $\mathrm{NaCl}$ (3.56\% wt/wt) are presented in table IV.

The pitting potentials displayed two tendencies. The first one referred to the comparison between the different materials in asreceived state. In this case, there was a clear quantitative correlation between the pitting potential and the chromium equivalent percentage; pitting resistance equivalent is PRE = Cr $\%+3$ Mo \%. Thus, stainless steel Type UNS S42000, with a chromium content of $14.3 \%$ and a pitting resistance equivalent of 14.45 (Table I), displayed the lowest pitting potentials in its different microstructural states. In general, the greater PRE is related with the higher pitting potential, i.e. it is nobler. Stainless steels Types UNS S31600 and S31603, in as-received state, displayed the noblest pitting potential. These materials have molybdenum, which is an element particularly active in the improvement of the pitting resistance in chloride media ${ }^{[32]}$.

The second tendency observed was the relationship between pitting potentials and the heat treatment state for each material. In austenitic stainless steels the pitting potential seems to be linked to the degree of sensitization of the material, i.e. when there was more chromium carbide precipitation or more chromium depleted zones, the pitting potential was lower.

The reduction in the value of the pitting potential obtained, in accordance with the heat treatment, was particularly strong in the noblest steel amongst those tested, i.e. stainless steel Type UNS S31603, but this behaviour in particular may be not representative of the steels of this type. The specific material tested seems to have a problem of contamination producing a strong surface sensitization with the heat treatment at $675^{\circ} \mathrm{C}$. This may have been the cause of the sharp drop (around $+650 \mathrm{mV}$ ) in the pitting potential of the material after the sensitizing heat treatment in relation to the solution annealed state.

Stainless steels Types UNS S30400, S30403 and S31600 suffered a lower drop in the pitting potential due to the sensitizing heat treatment in comparison with the Type UNS S31603. This was due to the fact that in these materials heat treatment produced a lower carbide precipitation at the grain boundaries ${ }^{[33]}$.

Stainless steel Type UNS S31600 presented a smaller decrease in the Ep due to a lower degree of sensitization. Types UNS S30400 and S30403 (without molybdenum) showed a higher decrease than the Type UNS S31600, possibly due to its molybdenum content. Stainless steel Type UNS S30403 had an Ep slightly lower decrease than the Type UNS S30400, which corresponds to the different sensitization states.

Stainless steel Type UNS S30300 had a general poor behaviour, independently of its heat treatment state, and worse than the other austenitic stainless steels tested, because this is a high sulphur free-machining stainless steel.

Stainless steel Type UNS S42000 exhibited the most cathodic pitting potential. The widest band of pitting potentials corresponded to the asreceived state, i.e. no sudden increase in the current density appeared in the anodic polarization curves when potential was modified, but rather a slow and progressive build-up. This may be connected with the fact that different sized pits were observed, which seems to indicate that the appearance of these pits took place gradually 
during the test. In as-quenched and tempered state the behaviour was assimilable to the as-received state, but with different behaviour in the two electrolytes tested. Similar results were previously found $d^{[34}$ and 35].

\subsubsection{Pitting potentials in Electrolyte $B$}

Table IV shows the pitting potentials obtained for each material in their different heat treatment states in a $\mathrm{NaCl}$ (3\% wt/vol) plus sulphides (SRB metabolites) medium.

When Electrolyte B was used (Table IV), in asreceived state, all the materials exhibited a higher degree of nobility than in the heat-treated state, although the differences expressed in $\mathrm{mV}$ were less than when Electrolyte A was used. It may be said that Electrolyte $\mathrm{B}$ gives higher sensitivity to the test, since it put in order the materials in accordance with their PRE with greater precision than Electrolyte A.

The correlations observed and discussed in the previous sub-section (Electrolyte A) between the heat treatment states and the pitting potentials for the different materials are maintained when we deal with Electrolyte B, with the difference that the $\mathrm{Ep}$ values obtained for the austenitic stainless steels tested in as-received state were lower for Electrolyte B than those obtained in the same conditions for Electrolyte A. This decrease in Ep potential in Electrolyte B was not maintained for the sensitized states, for which the Ep obtained were of the same level in Electrolytes A and B. The fact that higher Ep values had not been obtained for the sensitized states with Electrolyte A than with Electrolyte B, as could be expected, seems to be connected with the pitting morphology detected in the sensitized austenitic stainless steels tested in Electrolyte A (localized in intergranular form), but further research is required to establish exactly this relationship.

\subsection{Analysis of the corrosion produced in the electrochemical tests}

Different forms of pits in accordance with different parameters (chemical composition, microstructure and medium) were observed.

Effect of chemical composition. In pits from electrochemical tests, produced in a medium with chlorides, morphological differences were observed between the austenitic stainless steels and stainless steel Type UNS S42000. The pits in the austenitic stainless steels Types UNS S30400, S31600 and S31603 in solution annealed state were surrounded by other smaller pits (Fig. 9). This same aspect was reported by Ruijini et al. ${ }^{[36]}$. These steels exhibited a large number of scattered small pits covering practically the whole area of the test specimen. Stainless steel Type UNS S42000, in as-received state, displayed always not many but larger pits. Its both low chromium content and low PRE (Table I) may perhaps determine this numerical and morphological difference.

Effect of microstructure. Depending on the heat treatment state, a morphological difference can be observed in the pits from electrochemical tests in a medium with chlorides and without sulphides.

For solution annealed austenitic stainless steels, defined pits with concentric figures were observed (Fig. 9). This difference may be due to the fact that for sensitized austenitic stainless steels the pitting potential is lower, so there are many possible places for pit nucleation, such as the grain boundaries with carbide precipitation and chromium depletion, and therefore there is no spot nucleation and subsequent pit development. However, in the solubilized steels, which are nobler, when the pitting potential is reached at higher potentials, there is a greater difference in potential between the pits and the base metal, which gives rise to the appearance of better defined pits.

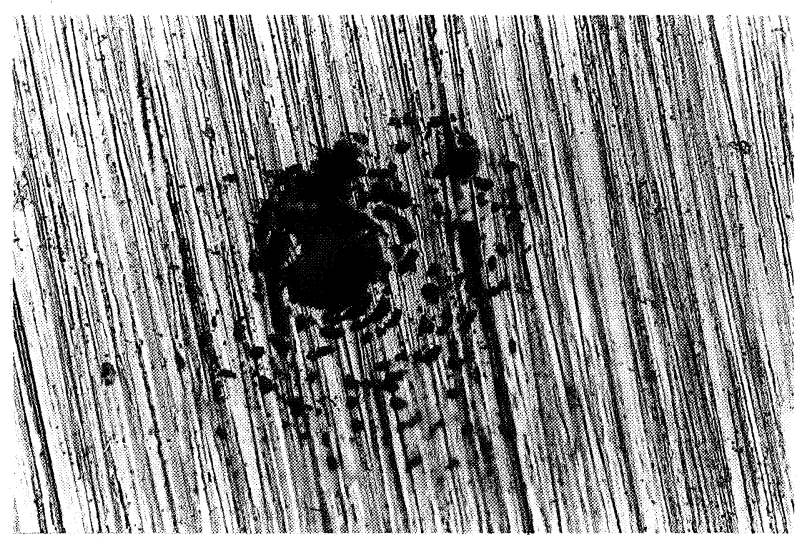

Figure 9. Pitting corrosion on stainless steel Type UNS S30400 as-received after an electrochemical test using Electrolyte $A(400 x)$ (Printing reproduction at $53 \%$ ).

Figura 9. Corrosión por picaduras, en el acero inoxidable UNS 530400 en estado de recepción, después de un ensayo electroquímico en el Electrólito $A(\times 400)$ (Reproducida en imprenta al $53 \%$ ). 
For martensitic stainless steel Type UNS S42000 was observed large pits irrespective of the heat treatment state (Fig. 10), although there is a relationship between the Ep values and the heat treatment state.

Effect of medium. When the medium contains chlorides and also sulphides -SRB metabolites-, it was found that the morphology of the pits was identical for all the steels tested irrespective of the heat treatment state (as-received or heat-treated).

Figures 6 and 11 show different materials tested in Electrolyte B. The electrochemical test with this electrolyte was followed visually, even though the pitting current did not reach $10-15 \mu \mathrm{A} / \mathrm{cm}^{2}$, because blackish spots formed on the test specimen, with "threads" of corrosion products, become detached from it as the current density increased. All the pits produced with this electrolyte had a coloured area around them.

In stainless steels Types UNS S30400 and S30300 with sensitizing heat treatment, perfectly defined pits were visible (Figs. 6 and 11), quite different from these obtained when Electrolyte A was used. Some of the pits were very deep $(71 \mu \mathrm{m}$ for stainless steel Type UNS S30400 with sensitizing heat treatment).

In some specific aspects (Figs. 6, 10 and 11) these pits were similar to other corrosion effects of biological origin (Fig. 5) and different from the pits

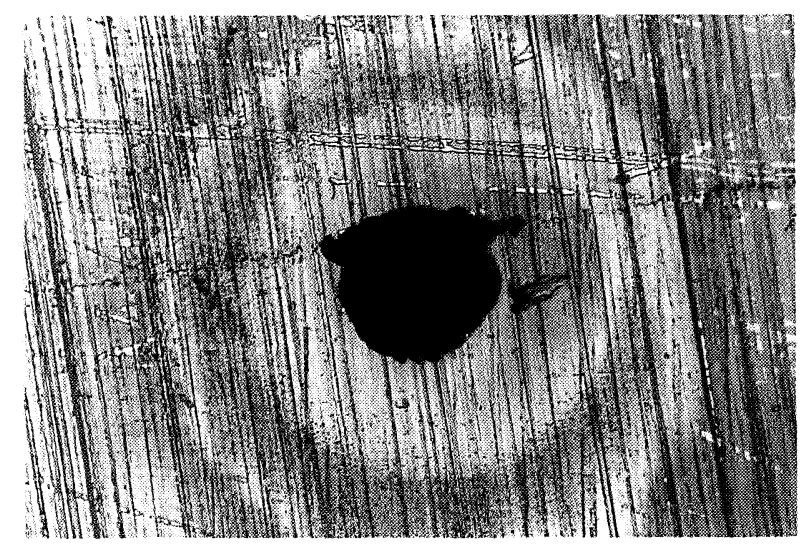

Figure 10. Pitting corrosion on stainless steel Type UNS S42000 quenched and tempered after an electrochemical test using Electrolyte B (400x) (Printing reproduction at $53 \%)$.

Figura 10. Corrosión por picaduras, en el acero inoxidable UNS S42000 templado y recocido, después de un ensayo electroquímico en el Electrólito $B(x 400)$ (Reproducida en imprenta al $53 \%$ ).

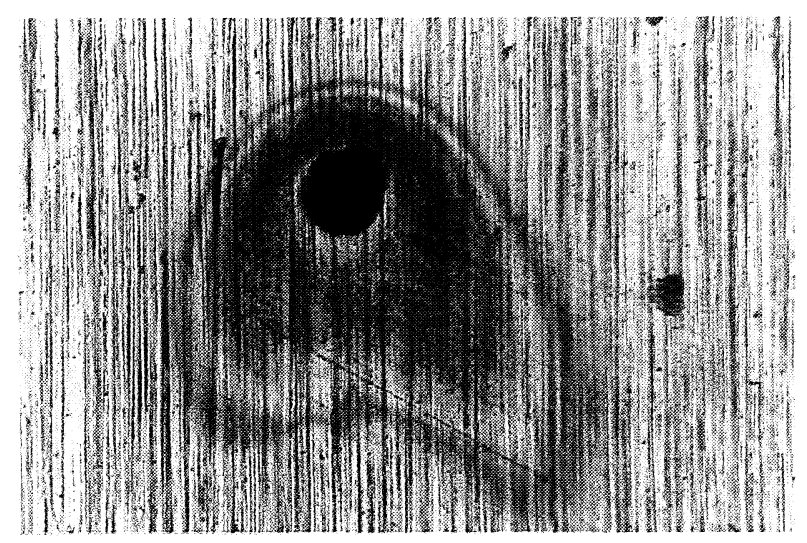

Figure 11. Pitting corrosion on stainless steel Type UNS S30300 sensitized after an electrochemical test using Electrolyte B (100x) (Printing reproduction at $53 \%$ )

Figura 11. Corrosión por picaduras, en el acero inoxidable UNS $\$ 30300$ sensibilizado, después de un ensayo electroquímico en el Electrólito B (x100) (Reproducida en imprenta al $53 \%)$.

obtained in a chloride medium for solutionannealed or sensitized austenitic stainless steels (Figs. 9 and 12).

The imperfect oxide layers formed in the presence of sulphides may perhaps justify the influence of the medium on the morphology of the localized corrosion ${ }^{[31]}$. This would entail the decrease in pitting potential. The pits are produced in accordance with the imperfections or

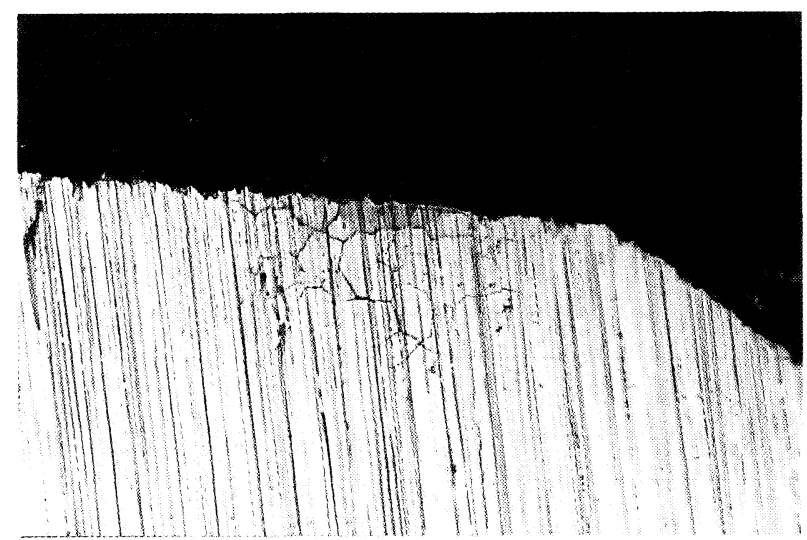

Figure 12. Localized corrosion on stainless steel Type UNS S31600 sensitized after an electrochemical test using Electrolyte A $(200 x)$ (Printing reproduction at $53 \%)$.

Figura 12. Corrosión localizada, en el acero inoxidable UNS S31600 sensibilizado, después de un ensayo electroquímico en el Electrólito $A(x 200)$ (Reproducida en imprenta al $53 \%$ ). 
heterogeneities of the layers, which would help to establish significant differences in potential in specific areas that have no reason to the grain boundary in sensitized austenitic steels.

\section{CONCLUSIONS}

- Martensitic stainless steel Type UNS S42000 in as-received state proved to be the most susceptible to pitting corrosion in a semicontinuous sulphate-reducing bacteria culture. In austenitic stainless steels no localized corrosion was observed after 60 days testing time. A testing time of more than 2 months is apparently required to start pitting in these materials. However, the electrochemical technique used revealed a positive behaviour and it was particularly sensitive and reproducible.

- It has been found that the difference in chromium content between the austenitic stainless steels in solution-annealed state and the martensitic stainless steel in the annealed state matches the differences in pitting potential in a chloride medium. This matching is even clearer in a medium of chlorides plus sulphides.

- The great influence of microstructure in the corrosion of stainless steels has been confirmed. In sensitized austenitic stainless steels, the production of chromium carbide precipitates and the presence of chromium depleted areas give rise to a reduction in the pitting potential. This decrease becomes more noticeable with the existence of sulphide precipitates in stainless steel Type UNS S30300. In the martensitic stainless steel no clear differentiation appeared between the annealed and the quenched and tempered states.

- The sulphides (sulphate-reducing bacteria metabolites) produced a premature rupture of the passivity of stainless steels in a chloride medium, inducing pit formation at more active potentials in comparison with the pits formed in chloride solutions.

- It has been established the correlation between pit morphology and chemical composition, microstructure (heat treatment), medium composition (chlorides or chlorides plus biogenic metabolites), and the type of test (biocorrosion tests or electrochemical tests).

\section{Acknowledgments}

This work was supported by Comisión Interministerial de Ciencia y Tecnología of Spain (CICYT, MAT90-0124).

\section{REFERENCES}

[1] J.D.A. Miller, Microbial Aspects of Metallurgy, Ed. Medical and Technical Publishing. Aylesbury, 1970.

[2] S.W. BORENSTEIN, Microbiologically influenced corrosion handbook. Industrial Press Inc. New York, 1994.

[3] G.G. GeEsey, Z. LeWANDOWskI and H.-C. Flemming, Biofouling and Biocorrosion in Industrial Water Systems. CRC Press Inc. Boca Raton, 1994.

[4] A.K. TILLER, Is stainless steel susceptible to microbial corrosion? Proc. of Microbial Corrosion, Ed. The Metals Society. London. Publ. No. 303, 1983, pp. 104-107.

[5] J.R. Ibars, D.A. Moreno and C. RanNinger, Microbiología 8 (1992) 63-75.

[6] R.E. TAtnalL, Mater. Perform. 20 (1981) 41-48.

[7] P.R. PUCKORIUS, Mater. Perform. 22 (1983) 19-22.

[8] J.G. StOECKER, Mater. Perform. 23 (1984) 48-55.

[9] G. KOBRIN, Reflections on microbiologically induced corrosion of stainless steels. Biologically Induced Corrosion, NACE-8, S.C. Dexter, Ed. National Association of Corrosion Engineers (NACE), Houston, Texas, 1986, pp. 33-46.

[10] J.G. StOECKER and D.H. POPE, Study of biological corrosion in high temperature demineralized water. Corrosion/86, Paper No. 126. National Association of Corrosion Engineers (NACE), Houston, Texas, 1986.

[11] D.H. POPE, A study of microbiologically influenced corrosion in nuclear power plants and a practical guide for countermeasures. Final Report EPRI NP-4582s. Research Project 1166-6, Palo Alto, California, 1986.

[12] J.L. Pintado and F. Montero, Rev. Iberoam. Corros. Prot. 17 (1986) 361-366.

[13] S.W. BORENSTEIN, Microbiologically influenced corrosion failures of austenitic stainless steel welds. Corrosion/88, Paper No. 78. National Association of Corrosion Engineers (NACE), Houston, Texas, 1988.

[14] G. KobRIN, Mater. Perform. 15 (1976) 38-43.

[15] P.J.B. SCOTT and M. DAVIES, Microbiologically influenced corrosion of high molybdenum austenitic stainless steel. Corrosion/89, Paper No. 186. National Association of Corrosion Engineers (NACE), Houston, Texas, 1989.

[16] G.J. LICINA, A review of microbial induced corrosion in nuclear power plant systems. Corrosion/88, Paper No. 268. National Association of Corrosion Engineers (NACE), Houston, Texas, 1988. 
[17] J.R. IBARS, D.A. MORENO and C. RANNINGer, Int Biodeterioration Biodegradation, 29 (1992) 367-375.

[18] G. DI CAPRIO, Los Aceros Inoxidables, Ed. Ebrisa, Barcelona, 1987. (Gli Acciai Inossidabili. Ed. Ulrico Hoepli, 1981)

[19] ASM, Properties and Selection: Irons, Steels, and High Performance Alloys. Metals Handbook, Tenth edition, Vol. 1, 1990.

[20] ASTM, Standard Practices for Detecting Susceptibility to intergranular attack in austenitic stainless steels. Book of Standards, Vol. 03.02, A-262, 1990.

[21] G.L. KEHL, Fundamentos de la Práctica Metalográfica. Ed. Aguilar, Madrid, 1949.

[22] D.A. MORENO and F. LABORDA, Sulphate- and sulphitereducing bacteria symbiosis in microbial corrosion. Microbial Corrosion 1. C.A.C. Sequeira and A.K. Tiller, Eds. Elsevier Applied Science, 1988, pp. 84-90.

[23] J.R. Postgate, The sulphate-reducing bacteria. Second edition. Ed. Cambridge University Press, 1984.

[24] H. CYPIONKA, J. Microbiol. Methods 5 (1986) 1-9.

[25] ASTM, Standard test method for conducting cyclic potentiodynamic polarization measurements for localized corrosion susceptibility of iron-, nickel-, or cobalt-based alloys. Book of Standards, Vol. 03.02, G61, 1986.

[26] D.A. Moreno, J.R. Ibars, C. RanNinger and H.A. VIDELA, Corrosion 48 (1992) 226-229.

[27] C.O. Obuekwe, D.W.S. Westlake, F.D. CoOK and J.W. COSTERTON, Appl. Environ. Microbiol. 41 (1981) 766-774.
[28] W.G. Characklis, Biofilm Development: A Process Analysis. Microbial Adhesion and Aggregation, Ed. K.C. Marshall, Springer-Verlag, 1984, pp. 135-157.

[29] P.J. WeIMER and T.K. NG: Use of two-stage continuous culture to assess biocorrosion by sulphate-reducing bacteria. Corrosion/88, Paper No. 90. National Association of Corrosion Engineers (NACE), Houston, Texas, 1988

[30] OCIDE, Corrosión Bacteriana de Aceros Inoxidables. Final Report, OCIDE Proj. No. 120.11, 1989.

[31] N.B. de Cristofaro, C.A. Acosta, R.C. Salvarezza and H.A. VIDELA, Corrosion, 42 (1986) 240-242.

[32] H. UNO, S. AKIYAMA, S. WADA and M. KOBAYASHI, Crevice corrosion of stainless steels in chloride solution. Corrosion/89, Paper No. 117, National Association of Corrosion Engineers (NACE), Houston, Texas, 1989.

[33] M.F.L. DE MEle, D.A. MOReno, J.R. Ibars and H.A. VIDELA, Corrosion 47 (1991) 24-30.

[34] J.R. IBARS, D.A. MORENO, M. LLORET and C. RANNINGER, Microstructural effects on the electrochemical behaviour of AISI 410 in microbiological media. Microbial Corrosion 1. C.A.C. Sequeira and A.K. Tiller, Eds. Elsevier Applied Science, 1988, pp. 287-299.

[35] D.A. MORENo, M.F.L. DE Mele, J.R. IBARS and H.A. VIDELA, Corrosion 47 (1991) 2-9.

[36] G. RUIJINI, S.C. SRIVASTAVA and M.B. IVES, Corrosion 45 (1989) 874-882. 